地質学雑誌 第 112 巻 第 7 号 486-489 ページ, 2006 年 7 月 Jour. Geol. Soc. Japan, Vol. 112, No. 7, p. 486-489, July 2006

討 論

\title{
高島千鶴*・狩野彰宏*：入之波温泉トラバーチンの堆積速度と日輪組織一「奈良県入之波温泉に発達する トラバーチンの堆積過程」へのコメントに対する回答
}

Chizuru Takashima* and Akihiro Kano* : Depositional rate and daily lamination of Shionoha hot spring travertine-Reply to the comments on "Depositional processes of travertine developed at Shionoha hot spring, Nara Prefecture, Japan".

\section{は じめに}

高島・狩野 (2005) は, 日本でも有数の規模でありなが ら,これまで科学的研究対象になっていなかった奈良県入之 波温泉のトラバーチンについて, 地球化学・鉱物学・堆積学 的なデー夕を提示し，いくつかの地点で採集した試料を対象 に堆積過程を中心に議論した. これに対し, 茂野氏は高島・ 狩野（2005）のデー夕をもとに独自の考察を行い, 主にト ラバーチンの堆積速度に関するいくつかの問題点を指摘する とともに, 日輪 (縞状組織) の生成機構について疑問を提示 した. 茂野氏が感じた問題点と疑問点の多くは, 私たちも共 有すると同時に, いくつかは回答可能なものである. 茂野氏 も指摘するように, トラバーチン研究に対する機運は, 多く の地球科学の分野で高まりつつあり, 私たちは今回の討論の 有用性を強く感じる.

茂野氏の 4 つの論点，1）沈殿物全体のマクロな成長速度 の見積り，2）非定常的な温泉水の化学組成の変化とその原 因，3）地点 5.0 の特異性とその原因，4）縞状組織の生成機 構の主要な部分は，A）堆積速度の問題と，B）日輪の生成 機構に集約されるだろう。したがって，今回は，これら 2 点 を中心に回答する.なお，日輪の存在と生成機構に関しては， 投稿後に行つた調査で，より重要な証拠を得て，研究が進行 している. 私たちは，その調査結果を昨年の日本地質学会第 113 年学術大会 (京都) で発表し, 公表論文を準備中である が，茂野氏の疑問に対し明確に回答するために，準備中論文 のオリジナリティーを妨げない程度に新規デー夕を提示す る.

\section{堆積速度について}

茂野氏も指摘しているように, トラバーチンの堆積作用は 時空的に極めて複雑な現象である。 その堆積速度を見積もる 方法として, 湧水点から下流までの水質変化と温泉水の流量 による計算（茂野氏の定義による生成速度），堆積物の成長 速度の実測（沈澱速度一以降, 茂野氏の定義に従う）が考え られるが，2つの結果が一致することはまれである. くしく

2006 年 6 月 16 日受付. 受理.

* 広島大学大学院理学研究科地球惑星システム学専攻

Department of Earth and Planetary Systems Science, Graduate School of Science, Hiroshima University, Higashi-Hiroshima 739-8526, Japan

Corresponding author: C.Takashima,tksmcdr@hiroshima-u.ac.jp
も茂野氏の計算により, 生成速度と地点 5.0 での成長速度が 偶然一致したが，地点 5.0 での比較的大きい流速（正の効果） と比較的低い $\mathrm{Ca}$ 濃度 (負の効果) が相殺されたものと考え られる.

2 つの速度の不一致の原因は, 沈澱速度が局所的な条件に 大きく左右されるためである. 水の化学成分に差異が無い場 合, 最も重要なのは流速である. 方解石の沈澱はトラバーチ ン表面で起こる. Dreybrodt and Buhmann (1991) のモデ ルによると, 流速の増加は水の摚汼を誘発し, 二酸化炭素の 脱ガスと溶存成分の効果的な拡散により沈澱速度を高める. 水/堆積物インターフェースにおいて, 沈澱を阻害する水素 イオンを排除し, 逆にカルシウム・炭酸イオンを供給するの である. すなわち, 段差上にある地点 5.0 は温泉水流路上に おいて比較的高い速度でトラバーチンが堆積する場所にな る. さらに, 浴槽排水の流出点直下 (地点 BT) では, 後述 する様に，一日の沈澱速度が，地点 5.0 の約 4 倍の, $2 \mathrm{~mm}$ 程度に達している. トラバーチンの沈澱速度は局所的に驚く ほど大きいのである.

また, 不一致の原因として, 水から核状物質として沈澱し, 浮遊流出する方解石微粒子の存在も無視できない（茂野, 1995). 入之波温泉水の流下水には, 多量の懸濁方解石が含 まれており，理論的には，

[生成量 $]=[$ 沈澱量 $]+[$ 懸濁方解石粒子量 $]$

という関係になるはずである，私たちは，流速や懸濁物量 についてのデー夕は採集しなかつたため, これらの問題につ いて議論することは避けたが, トラバーチン堆積場での現象 を理解するためには，今後検討すべき事柄である.

次に, やや重要度は低いが, 茂野氏の議論 2 について回答 したい, 茂野氏は観測日によって, 流出区間でのカルシウム 濃度変化パターンが異なり（茂野氏の Fig. 1), 非定常的で あると指摘した．この非定常性は「方解石沈澱はトラバーチ ン表面で起こる」という原則で部分的に説明される. 水/堆 積物インターフェースでの方解石沈澱速度が一定であると仮 定すると, 温泉流下水のカルシウム濃度減少幅は, 水の流下 に要する時間が長く, 水深が浅い（水の層が薄い）ほど大き くなる. 入之波温泉では, 活発なトラバーチンの沈澱により, 水の流下経路が頻繁に変化する. その変化はトラバーチンド 一ム上で特に大きく, 水がドーム上を広く薄く流れる時もあ れば，狭く厚く流れる時もある，おそらく，こうしたトラバ 


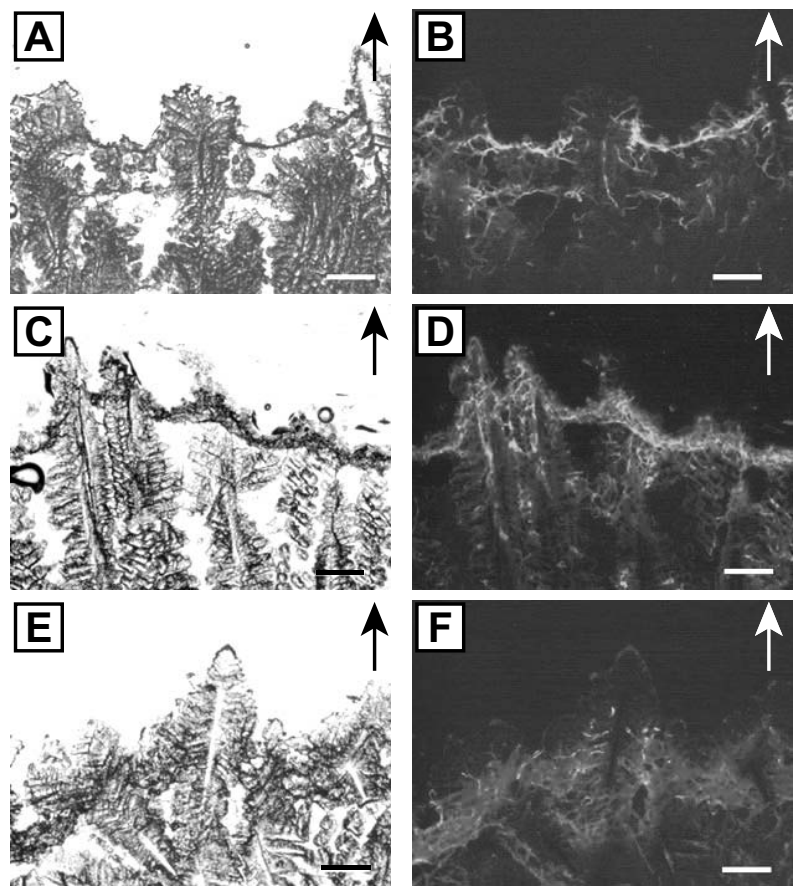

Fig. 1. Thin sections of daily laminated travertine surfaces collected at point 3.5 in Yamabato-yu, Nara Prefecture, Japan. A) The specimen at 10:30 on March 14, 2005. B) Fluorescence image of Fig. 1A. C) The specimen collected at 19:30 on March 14, 2005. D) Fluorescence image of Fig. 1C. E) The specimen collected at 4:30 on March 15, 2005. F) Fluorescence image of Fig. 1E. All scale bars are 250um long. Fluorescence from photosynthetic pigment appears lighter-color images.

一チンドーム上での流路の変化がカルシウム濃度の非定常性 につながつたのだろう。茂野氏の Fig. 1 に示される様に，非 定常性はトラバーチンドームの地点 3.0 で最大になってお り，この地点で最も $\mathrm{Ca}$ 濃度の高い 2004 年 4 月 19 日には狭 く厚く, 逆に濃度の低い 2003 年 9 月 22 日には広く薄く流 下していたのだろう。 なお, 茂野氏が非定常性の原因として 指摘した, 温泉水湧出量の変化も可能性として挙げられる. 入之波温泉では, 坑井孔内でも方解石の沈澱が起っており, 孔径の減少により, 次第に湧出量が減少するらしい. そのた め, 定期的に坑井から沈澱物を取り除き, 豊富な湧出量を確 保しているという. 湧出量が増加すれば, 単位水量あたりの 方解石生成量が減少するので, 流出区間でのカルシウム濃度 変化は 2004 年 4 月 19 日の様なパターンを描くと予想され る.

\section{日輪（縞状組織）の生成過程}

地点 5.0 および 3.5 で堆積したトラバーチンの内部には, 数 $100 \mu \mathrm{m} \sim 1 \mathrm{~mm}$ オーダーの縞状組織が認められる. 縞状 組織は, 細粒方解石主体の暗灰色層と, 杉の葉状構造を作る 菱形の方解石結晶からなる白色層で構成される. 高島・狩野 （2005）は，これが人為的影響を受けずに発達した日輪であ ると結論付けるために，1）地点 5.0 で，41 日間に堆積した

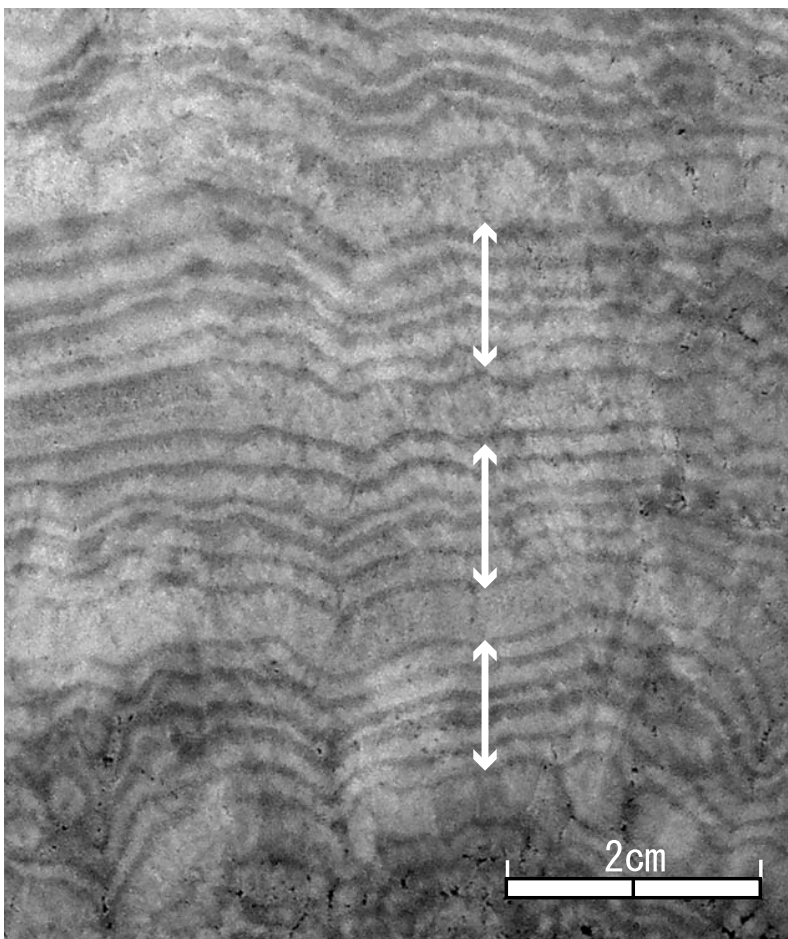

Fig. 2. Travertine deposited at just below the drainage from the public bath, point BT in Takashima and Kano (2005) The scale bar is $2 \mathrm{~cm}$ long. It represents sets of 6 darker-colored bands (arrows), which were formed in influence from cleaning. The intervals between the sets correspond to regular holiday of Yamabato-yu (Wednesday).

トラバーチン内部に約 40 本の縞が発達すること, 2）地点 3.5 の堆積物内部にも, 地点 5.0 と同様の縞状組織が発達す ること，3）地点 3.5 の水・堆積物には, 人為的影響が無い こと, を証拠として挙げた. しかし，その生成過程について は微生物の影響を暗示したものの, 明確な結論は下さなかつ た，それは，証拠が不足していたからである，そこで，日輪 の生成過程について検討するため, 高島・狩野（2005）の 投稿後の 2005 年 3 月に, 人為的影響が無い地点 3.5 で 30 時間連続観測を行った. その結果, 私たちは以下に示す証拠 により, 日輪が光量の変化に対応した微生物活動の日変化に より生じると結論付けるに至った.

地点 3.5 での堆積物最表面の組織は, 時間を追って明確に 変化している (Fig. 1). 細粒方解石主体の暗灰色層が表面に 発達していたのは，日没後（19:30）に採集した試料（Fig. 1C）のみであり，その他の時間帯に採集した堆積物試料 (Figs. 1A；10:30, 1E；4:30）の最表面には, 菱形の方解石結 晶（白色層）が認められた。これは, 暗灰色層が日没後の限 られた時間で形成されたことを意味する，さらに，これらの 薄片の蛍光顕微鏡画像 (Figs. 1B, 1D, 1F) では, 暗灰色層 中に, 赤い自家蛍光体を示す（Fig. 1 では, 白く見えている部 分）フィラメント状シアノバクテリアが確認された.

すなわち, 暗灰色層の形成には, シアノバクテリアが重要 な役割を果たしていると言える. シアノバクテリアは光合成 細菌であるが, 直射日光を嫌い暗所に留まる性質を持つ（藤 
岡・大城, 1989). 日中, 杉の葉状方解石結晶間のスペースに 留まっていたシアノバクテリアは, 日没後に, トラバーチン 表面に成長してくる. 光が無くても細胞外生成物である EPS (extracellular polymeric substance) は生成され，トラバー チン表面にバイオフィルムを形成する，そうすると，表面は 粘着質になり，上流から運搬された細粒方解石懸濁物をトラ ップすることになる. こうして発達したのが暗灰色層である. バイオフィルム表面は，夜半には懸濁物で覆われ，そこから 再び方解石沈殿が開始し，白色層の発達が始まる。詳しくは 解説しないが，1）暗灰色層には湧水付近で多く沈殿する Fe と Si が多く含まれること，2）地点 3.5 での水中の懸濁物量 が日没後に最小量を記録したことも，暗灰色層がトラップさ れた懸濁物であることを支持する．また，水の化学成分（Ca 濃度や方解石過飽和度）の昼夜における差は小さく, その日 変化が日輪形成に関与したとは考えにくい．以上をまとめる と, 日輪の形成は, 化学的過程ではなく, 光量の日変化に応 じた微生物学的過程により自然に起こったと結論付けられ る.

ただし, 局所的には人為的プロセスにより日輪が発達する. Fig. 2 に示す試料は浴槽排水口の直下（高島・狩野, 2005 の 地点 BT）から採集したもので，ほぼ等間隔で発達する明瞭 な褐色のバンドを示す。さらに，やや間隔が広い部分を隔て て，バンドは 6 本毎のセットになっている，高島・狩野 （2005）でも述べたが，入之波温泉では，営業日の終わりに 浴槽を清掃し，その際に多量の懸濁物が流出する．褐色のバ ンドはその時にトラバーチン表面に沈着したものである可能 性が高く，人為的な日輪組織である。なお，入之波温泉は毎 週水曜日に休業し清掃を行わない。したがつて，6 本のバン ドのセットは木曜日から次週火曜日の清掃時に沈澱したもの であると考えて良いだろう。 人為的影響は浴槽排水口付近で の夕顕著である，高島・狩野（2005）が記載の対象とした 地点 3.5 と地点 5.0 のトラバーチンには，このような 6 本セ ットのパターンは認められない（高島・狩野, 2005 の Figs. 6C，6F). したがって，これらの縞状組織の発達には，清掃 という人為的影響が関与していないと考えてよい。

\section{定 義の問 題}

その他, 茂野氏には多くの有用なコメントをいただいたが, 中でも重要と思われる「言葉の定義の問題」について，私た ちなりの考えを回答させていただきたい.

茂野氏の指摘通り，陸域炭酸塩沈澱物の分類には混乱が残 されている. かつては, 温泉・冷泉の区別なく，泉源水から 沈殿した炭酸塩堆積物に対して, ドイツ学派はトゥファを, イタリアーアメリカ学派はトラバーチンを用いる傾向があっ た。しかし，私たちは Ford and Pedley（1996）の定義に従 い，温泉水からの沈殿物をトラバーチン，石灰岩層中の地下 水系から湧出する天水起源の水から沈殿したものをトゥファ と呼ぶことにしている. この定義は広く受け入れられつつあ り，少なくとも，温泉沈殿物をトゥファと呼ぶ研究者はいな くなつた

泉源水からの炭酸塩沈殿物を天水成と温泉水成に分けるこ
とは意味がある. 前者の泉水は土袞起源の二酸化炭素を含ん だ雨水であるため, 水量や溶存炭酸の量は降水量や土壌層中 での有機物の分解量に関係する。 そこで，トゥファの組織 的・組成的特徵は気候条件に強く影響される（末岡ほか, 2002; Kano et al., 2003). 一方, 後者の場合, 水の化学的特 性は地表気候の季節変化に影響されないので, トラバーチン の中には気候変化が記録されにくい. また，両者の化学組成 も著しく異なる. Pentecost（1995）のまとめによると, ト ウファを堆積させる天水起源の水の総溶存無機炭素（TDIC） は $1 \sim 7 \mathrm{mM}$ (約 $60 \sim 430 \mathrm{ppm}$ ) 程度である. 一方，トラ バーチンを沈殿する温泉水の場合, TDIC は概して天水成泉 水よりもはるかに大きく, 15〜 60 mM (約 $900 〜 3700$ ppm) に達する. さらに, これを反映し, 両者は堆積速度の点でも 大きく異なる. 堆積速度は, トゥファでは $1 \mathrm{~cm} /$ 年を越え ることはまれであるのに対し，トラバーチンでは高島・狩野 （2005）で示したように $10 \mathrm{~cm} /$ 年をはるかに越えることが ある.

茂野氏が提案するような，沈殿物の性状（緻密さ・硬さ） で炭酸塩沈澱物を定義する事には科学的な意味で抵抗を感じ る. 具体的なデー夕を提示出来ないのが残念だが, 堆積物の 硬さは流速に応じて局所的に変化する. 同じトラバーチンの 堆積場でも, $10 \mathrm{~cm}$ ほど離れると硬さが大きく違う場合があ り，それを根拠に別の名前を使用するのは，記載を煩雑にす る原因になるだろう.

\section{おわりに}

高島・狩野（2005）では，多くの地球化学・鉱物学・堆 積学的なデー夕を提示したにもかかわらず, 議論を堆積過程 など特に重要な問題に限定し，必要最小限にとどめた。 それ は，「地質学雑誌」のページ数制限を考慮したことに加え， 議論に必要なデー夕が完備されていなかつたためである.今 回, 茂野氏から討論の申し出があり, 論文に欠けていた議論 を補充するとともに，日輪の生成機構に関する説明を補強す ることができた．また，トラバーチンの堆積速度について私 たちの考えを整理する契機にもなつた. 討論の機会を与えて いただいた茂野氏と編集幹事の方には感謝したい.

茂野（1995）が述べているように，国内外には様々な特 徵をもつトラバーチン堆積物が発達している. 今回の議論の 対象になった日輪組織のように，トラバーチンに認められる 堆積組織の生成過程には，まだまだ多くの謎が残されている と言える. 今後は, 従来の研究例をレビューするとともに, 独自のケーススタディを重ねて, トラバーチン堆積組織につ いての理解を深めていきたい。 また，より総合的な視野で, トラバーチン堆積機構の一般性と局所性について研究を進め ていきたい

\section{謝辞}

山鳩湯の皆様には調査を快諾していただくとともに, 様々 な便宜を計っていただいた，広島大学の川合達也氏・堀 真 子氏，ゲッチンゲン大学の白石史人氏には，日輪トラバーチ ンの連続観測に協力していただいた．以上の方々に深く感謝 
します.

\section{後}

記

被討論論文（高島・狩野, 2005, 地質学雑誌, 111 巻 12 号, 751-764 頁) には以下の誤りがあったので，この機会にお詫 びとともに訂正させていただきます.

752 頁 左段 : (誤) N $34^{\circ} 25.3^{\prime}, \mathrm{E} 135^{\circ} 56.2^{\prime} \rightarrow$ (正) N $34^{\circ}$ $15 ' 43^{\prime \prime}, \mathrm{E} 136^{\circ} 02^{\prime 2} 25^{\prime \prime}$

759 頁 Fig. $6 \mathrm{H}$ のキャプション : (誤) Tree-tree structure $\rightarrow$ (正) Cedar-tree structure

763 頁＼cjkstart文献：(誤) Matsuoka, J., Kano, A., Oba, T., Watanabe, T., Sakai, S. and Seno, K., 2001, Seasonal variation of stable isotopic compositions recorded in a laminated tufa, SWJapan. Earth Planet. Sci. Lett., 191, 31-44. $\rightarrow$ (正) Matsuoka, J., Kano, A., Oba, T., Watanabe, T., Sakai, S. and Seno, K., 2001, Seasonal variation of stable isotopic compositions recorded in a laminated tufa, SW-Japan. Earth Planet. Sci. Lett., 192, 31-44.

文献

Dreybrodt, W. and Buhmann, D., 1991, A mass transfer model for dissolution and precipitation of calcite from solutions in turbulent motion. Chem. Geol., 90, 107-122.

Ford, T.D. and Pedley, H.M., 1996, A review of tufa and travertine deposits of the world. Earth-Sci. Rev., 41, 117-175.

藤田善彦・大城 香, 1989, ラン藻という生き物. 東京大学出版会, 134p.

Kano, A., Matsuoka, J., Kojo, T. and Fujii, H., 2003, Origin of annual laminations in tufa deposits, southwest Japan. Palaeogeogra. Palaeoclimatol., Palaeoecol., 191, 243-262.

Pentecost, A., 1995, The Quaternary travertine deposits of Europe and Asia Minor. Quaterm. Sci. Rev., 14, 1005-1028.

茂野 博, 1995 , 温泉沈殿物による棚田状テラス生成の機構と数值シミ ユレーション. 地熱, 32, 317-336.

末岡正嗣 - 狩野彰宏 - 古城智子 ・ 松岡 淳 - 井原拓二, 2002 , 徳之島西 部に発達するトゥファの特徵. 地質雑, 108, 153-163.

高島千鶴・狩野彰宏, 2005 , 奈良県入之波温泉に発達するトラバーチン の堆積過程. 地質雑, 111, 751-764. 